\title{
Frequency and foraging behavior of Apis mellifera in two melon hybrids in Juazeiro, state of Bahia, Brazil
}

\author{
LÚCIA H.P. KIILL ${ }^{1}$, KÁTIA M.M. SIQUEIRA ${ }^{2}$, MÁRCIA S. COELHO ${ }^{1 *}$ TAMIRES A. SILVA $^{1 * *}$, \\ DIEGO R.S. GAMA ${ }^{2 * * *}$, DIEGO C.S. ARAÚJO ${ }^{2 * * *}$ and JOAQUIM PEREIRA NETO ${ }^{2}$ \\ ${ }^{1}$ Embrapa Semiárido, BR 428, Km 152, s/n, Zona Rural, Caixa Postal 23, 56302-970 Petrolina, PE, Brasil \\ ${ }^{2}$ Departamento de Tecnologia e Ciências Sociais, Universidade do Estado da Bahia/ UNEB, Campus III, \\ Avenida Edgard Chastinet, s/n, São Geraldo, 48905-680 Juazeiro, BA, Brasil
}

Manuscript received on September 16, 2013; accepted for publication on May 5, 2014

\begin{abstract}
The study was carried out to verify if there are differences in foraging frequency and behavior of Apis mellifera in two melon hybrids (10:00 - 'Yellow melon' and Sancho -'Piel de Sapo') in the municipality of Juazeiro, state of Bahia, Brazil. The frequency, behavior of visitors and the floral resource foraged were registered from 5:00 am to 6:00 $\mathrm{pm}$. There was a significant difference in the frequency of visits when comparing hydrids $(\mathrm{F}=103.74, \mathrm{p}<0.0001)$, floral type $(\mathrm{F}=47.25, \mathrm{p}<0.0001)$ and resource foraged $(\mathrm{F}=$ $239.14, \mathrm{p}<0.0001$ ). The flowers of Sancho were more attractive to $A$. mellifera when compared with hybrid 10:00, which may be correlated to the morphology and floral resources available. This could be solved with scaled planting, avoiding the overlapping of flowering of both types.
\end{abstract}

Key words: Cucumis melo L, melon hybrids, nectar, pollen.

\section{INTRODUCTION}

The dependence of biotic pollinating agents for reproductive success is common among fruit crops. It is estimated that $75 \%$ of the cultures and $80 \%$ of the plants with flowers depend of pollination made by biotic agents, among which bees are the most known (Imperatriz-Fonseca and Nunes-Silva 2010). The temporal and spacial distribution of the diversity of pollinators and pollination services are important for the preservation of native plants and animals and also to maintain a good productivity of the crops as well (Garibaldi et al. 2011).

Correspondence to: Lucia Helena Piedade Kiill

E-mail: lucia.kiill@embrapa.br

*Bolsista DTI/CNPq

**Bolsista Funbio - MMA/FAO

***B Bolsista PIBIC/CNPq
The melon (Cucumis melo L.) is among the fruit crop that needs pollination services and depends mainly of honeybees (Apis mellifera L.Hymenoptera: Apidae) to guarantee its fruit quality and productivity (Kouonon et al. 2009, Sousa et al. 2009). Normally, big cultivated areas do not have enough pollination agents and nice areal distribution to guarantee good yield. Therefore, it is necessary to move beehives into the crops in order to address this demand. Low levels of pollination in melon crops can contribute to limiting the production expression of the cultivated material for both the yield and the quality of the fruits.

Comparative studies among melon cultivars are rare in literature. In an experimental area with 'Yellow melon' (BRS Araguaia), 'Piel de Sapo' 
(P-33) and Cantaloupe (Can-4) cultivars, Kiill et al. (2011) found differences in relation to visitation peak of A. mellifera and the floral type visited, yet no differences were observed in relation to foraged resource by the bees. The present study was, therefore, carried out to verify if there are differences in the frequency and foraging behavior of the floral visitors in the melon hybrids (10:00 - 'Yellow-melon' and Sancho 'Piel de Sapo') of a commercial area in the municipality of Juazeiro, state of Bahia, Brazil.

\section{MATERIALS AND METHODS}

The study was carried out in July 2010 in a commercial area of three hectares of melon, located in the Irrigation Project of Mandacaru in the municipality of Juazeiro $\left(09^{\circ} 24^{\prime} \mathrm{S}, 40^{\circ} 26^{\prime} \mathrm{W}\right)$, state of Bahia, Brazil. Two melon hybrids 10:00 'Yelow melon' (2.8 ha) and Sancho 'Piel de Sapo'(0.2 ha) were used. They were cultivated in a conventional system with mulching and drip-irrigation, without the addition of Apis mellifera hives.

The observations were made 40 days after transplantation, when the highest number of hermaphrodite flowers were found, excluding the days in which pesticides were being sprayed. Daily and simultaneous observations were made to register floral visitors, on both floral types (five male and five hermaphrodite flowers) in both melon hybrids.

The frequency and behavior of the visitors, as well as the floral resource foraged were registered from 5:00 am to $6: 00 \mathrm{pm}$, in five non-consecutive days, totaling 130 hours of observation work for both melon hybrids. The presence of visitors was registered and data analyses in relation to the time of visit, floral type and floral resource foraged by visitors, were performed. With regards to the floral resource, it was considered pollen's visits when the bee contacted only the reproductive structure to these and nectar's visit when the bee introduced the mouthparts into the flower to access the nectariferous chamber.
For the analyses of variance, visitation dates were transformed by using $\sqrt{\text { number of visits }+0.5}$. Data normality and homogeneity of variances were verified by Shapiro-Wilk and Bartlett test, respectively. Analyses were carried out using the SAS ${ }^{\circledR}$ Statistical Software v.9.3 (SAS Institute 2003).

\section{RESULTS}

The floral biology of the two melon hybrids were similar, being anthesis of the male and hermaphrodite flowers registered around 5:00 am. The senescence of the flowers started around 5:00 pm, observed by dehydration and color change of petals. The process was finalized around 6:00 pm when the petals appeared totally shriveled, closing the access to the flower's interior. Thus, the lifetime of the flowers was approximately 12 hours.

In the observations the melon flowers were visited mainly by $A$. mellifera with 541 and 2050 visits registered during the entire experimental period for the hybrids 10:00 and Sancho, respectively. Sporadic visits of Xylocopa grisescens (Hymenoptera: Apidae) ( $\mathrm{n}=2$ visits) on the Yellow melon hybrid flowers and a nonidentified moth ( $\mathrm{n}=1$ visit) on the Sancho hybrid flowers were also observed, which represents less than $1 \%$ of total visitations.

Significant differences were observed in the visitations of $A$. mellifera between melon hybrids $(\mathrm{F}=103.74 ; \mathrm{p}<0.0001)$, floral types $(\mathrm{F}=47.25$; $\mathrm{p}<0.0001)$ and foraged resources $(\mathrm{F}=239.14$; $\mathrm{p}<0.0001)$. The total visitation of $A$. mellifera per day in two melon hybrids is shown in figure 1. It shows the Sancho flowers received more daily visits than 'Yellow' hybrid flowers $\left(\chi^{2}=28.510\right.$; df. $4 ; \mathrm{p}<0.0001)$.

Figure 2 shows the frequency of Apis mellifera per melon hybrids and by time interval. Sancho flowers always received more visits than the 'Yellow' hybrid flowers $\left(\chi^{2}=62.585\right.$; df. 12, $\mathrm{p}<0.0001$ ), except in the interval of 6:00 am to 


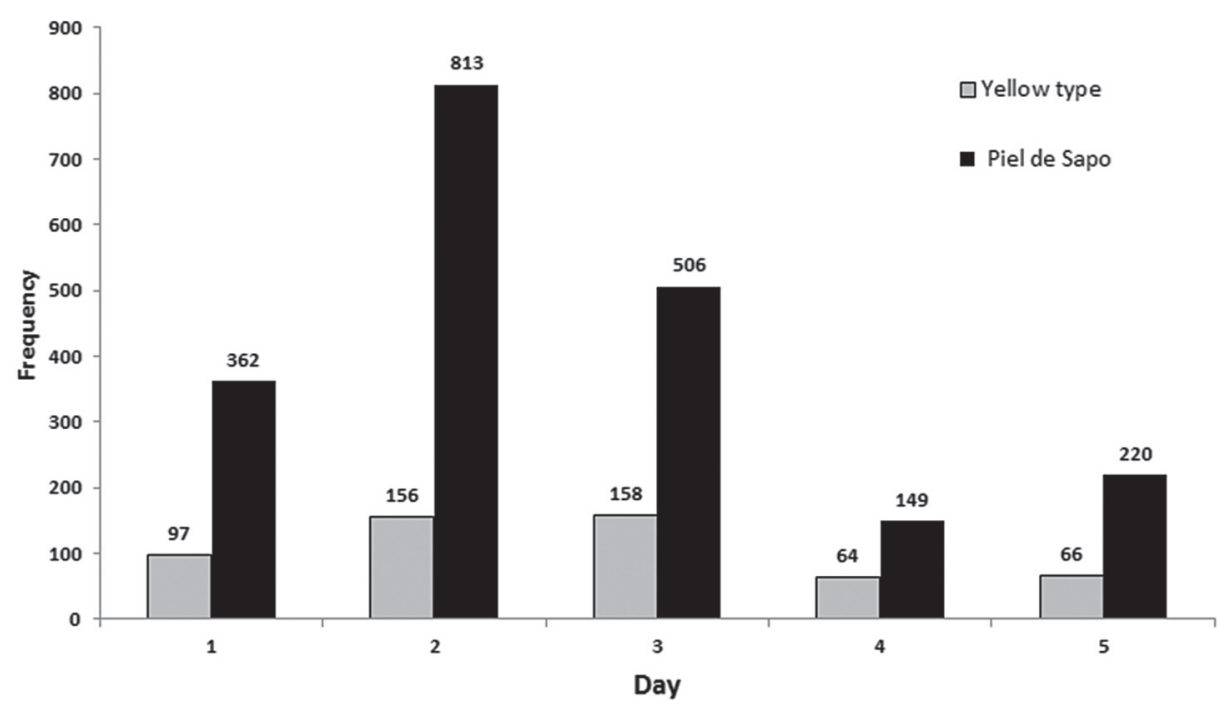

Figure 1 - Frequency of visits of $A$. mellifera per hybrids and per observation day, in a commercial crop in the Irrigation Project of Mandacaru, in the municipality of Juazeiro, state of Bahia, Brazil.

7:00 am, when they were similar. Few visits were observed in both hybrids of melon at early morning, and between 5:00 am to 6:00 am visits were observed only in the Sancho flowers. In general, it was found that in both melon hybrids the pattern of visitation was ascending during the morning with concentration between 9:00 to 11:00 am. After this time the pollinators activity decreased going up between 1:00 pm to $3: 00 \mathrm{pm}$, but only in the Sancho flowers.

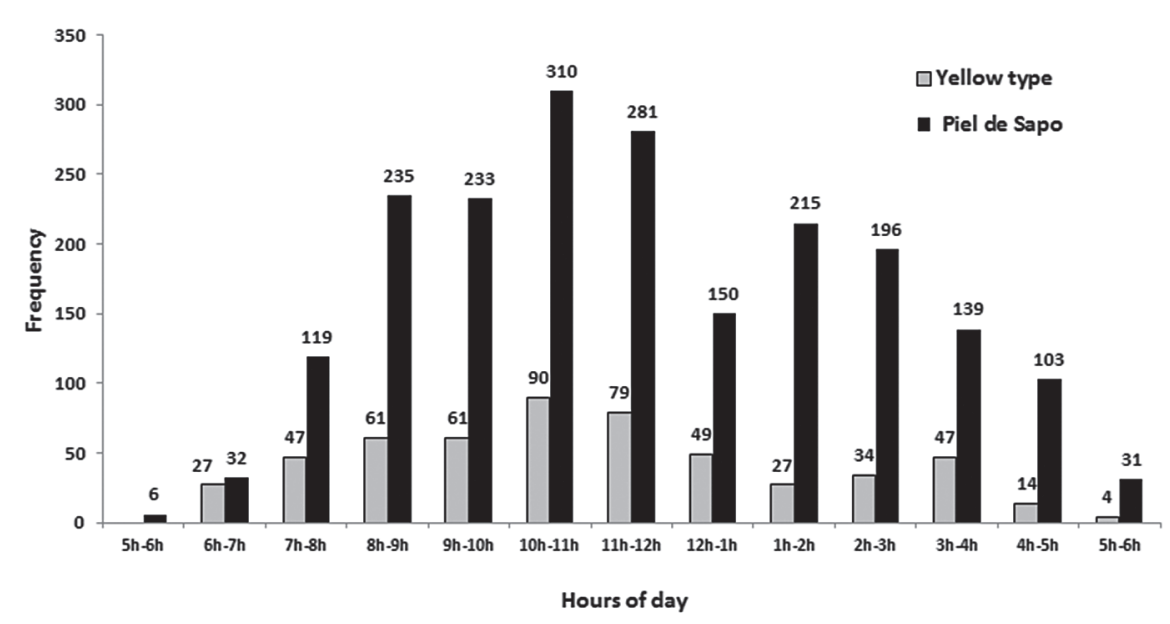

Figure 2 - Frequency of visits of A. mellifera per hour in two melon hybrids in a commercial crop in the Irrigation Project of Mandacaru, in the municipality of Juazeiro, state of Bahia, Brazil.

Analysing the visits in different melon hybrids and floral types (Fig. 3), it was found in both cultivars that hermaphrodite flowers received more visits than the male flowers, although the male floral type was produced in more quantity by the plants.
Comparing melon hybrids it was found that the hermaphrodite flowers of Sancho was visited 3.5 times more than those of 'Yellow' hybrid, and this difference was even greater when comparing the visits reported in male flowers (4.2 times greater). 


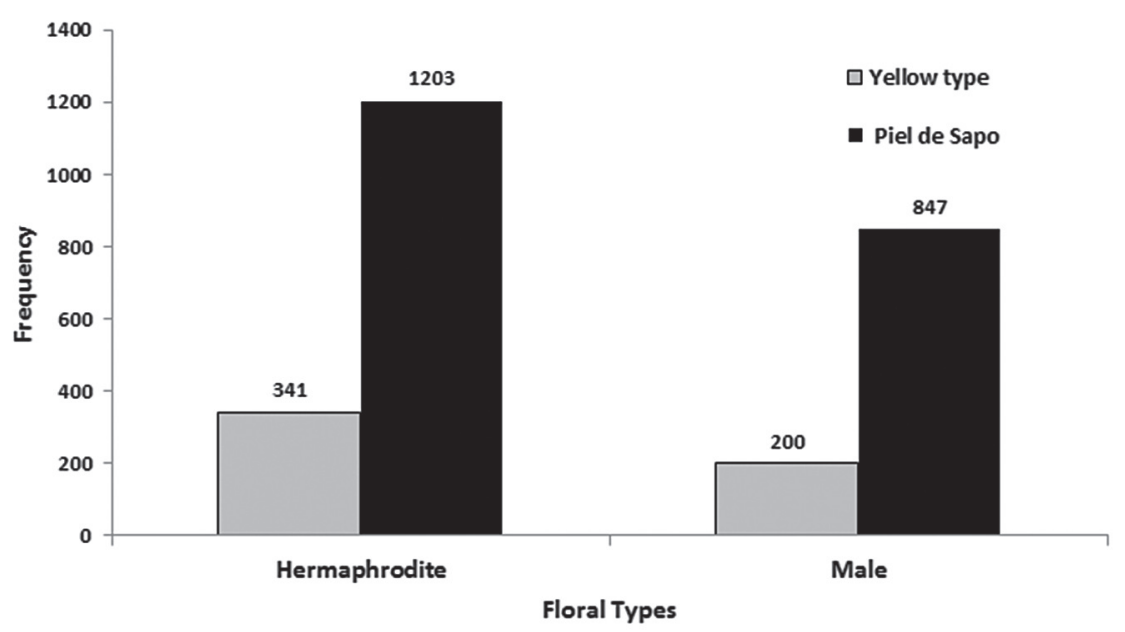

Figure 3 - Frequency of visits of $A$. mellifera per floral type in two melon hybrids in a commercial crop in the Irrigation Project of Mandacaru, in the municipality of Juazeiro, state of Bahia, Brazil.

Regarding the foraged resource during visits of Apis mellifera (Fig. 4) it was found, in both melon hybrids that the frequency of visits was two (Sancho) and three ('Yellow' hybrid) times greater for nectar collection $\left(\chi^{2}=24.673\right.$; df $\left.1, \mathrm{p}<0.0001\right)$ and this kind of visit in the Sancho was three times more than in the 'Yellow' hybrid. An even greater difference (four times more) was found when the visits for pollen collection in both melon hybrids were compared.

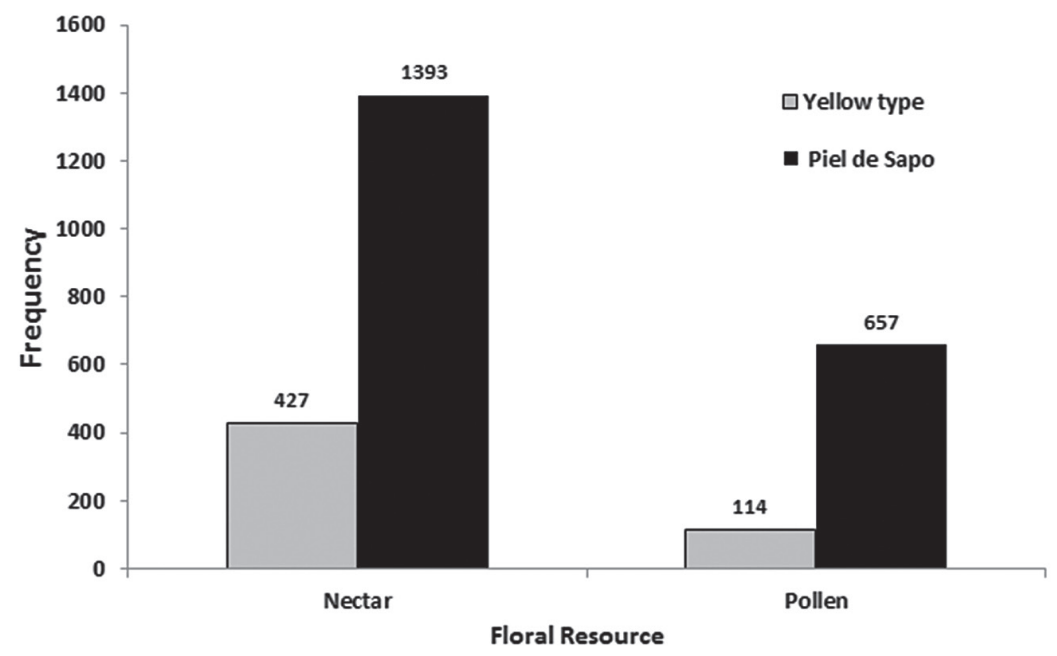

Figure 4 - Frequency of visits of A. mellifera per floral resource foraged in two melon hybrids in a commercial crop in Irrigation Project of Mandacaru, in the municipality of Juazeiro, state of Bahia, Brazil.

Comparing the frequency of visits per floral type and resource it was found that the hermaphrodite flowers are more visited than the male flowers for the collection of nectar and pollen foraging (Fig. 5). According to figure 6, there was difference in the frequency of $A$. mellifera visits in relation to resource foraged $\left(\chi^{2}=476.880\right.$; df 12 , $\mathrm{p}<0.0001$ ), with pollen collection reported mainly in the morning. As for the nectar, the frequency of visits was ascending until late morning, showing decline during the afternoon, however, with values higher than those recorded for pollen. 


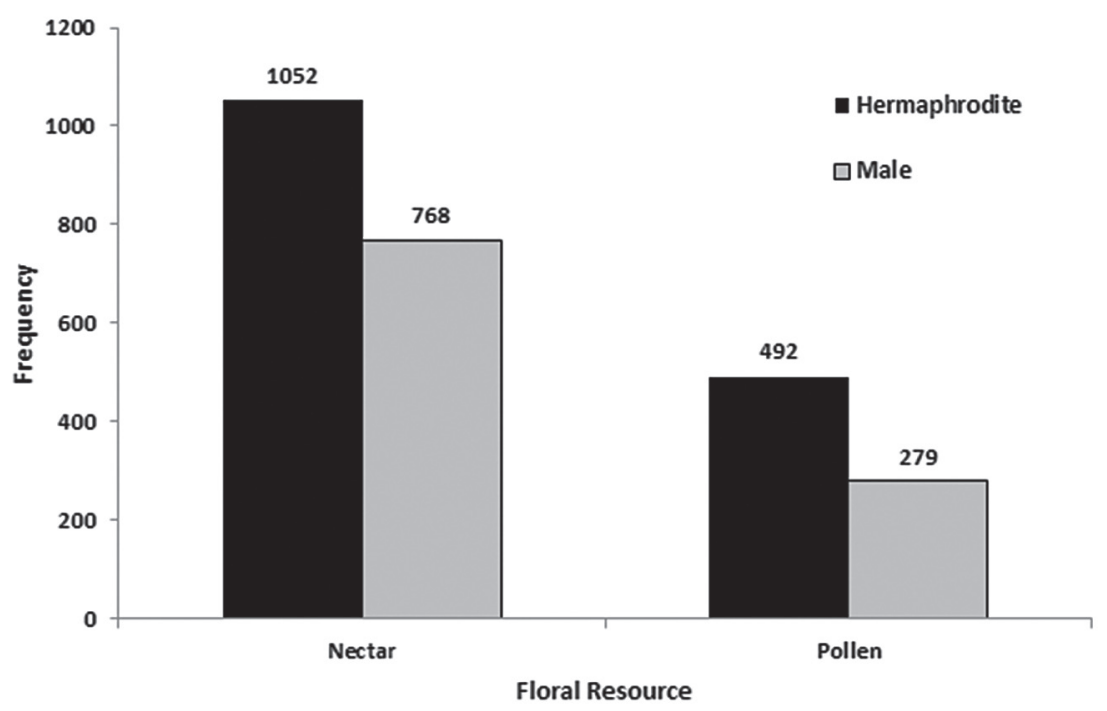

Figure 5 - Frequency of visits of $A$. mellifera per foraged resource and per floral type in hermaphrodite and male flowers in a commercial crop in Irrigation Project of Mandacaru in the municipality of Juazeiro, state of Bahia, Brazil.

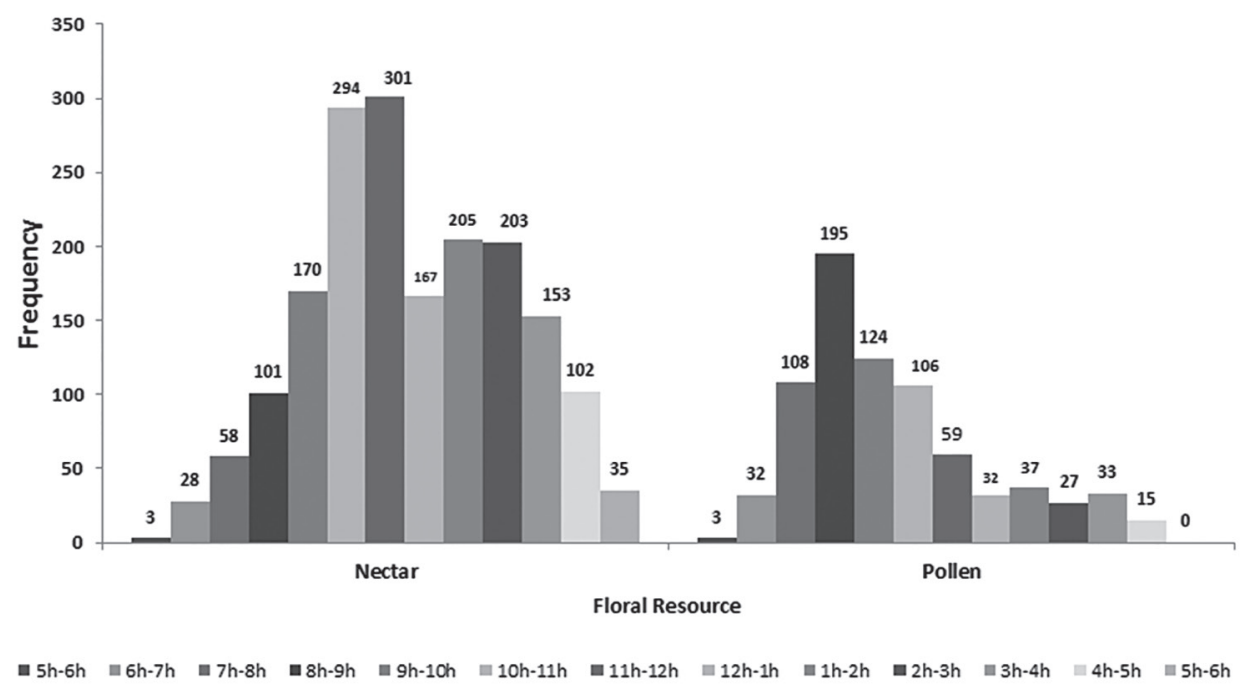

Figure 6 - Frequency of visits of $A$. mellifera per foraged resource, per hour, in a commercial crop in Irrigation Project of Mandacaru, in the municipality of Juazeiro, state of Bahia, Brazil.

\section{DISCUSSION}

The results of the floral biology showed no differences in anthesis and senescence between floral types and melon hybrids studied, in accordance with the pattern described for Brazil (Abreu et al. 2008), but different from that found in Mexico where the flowers were open and receiving visitors up to 8:00 pm (Reyes-Carrillo et al. 2006).
In relation to flower visitors, Apis mellifera was the most frequent pollinator although the flowers of melon can also be attractive to other insects. The presence of this bee in cultivated areas can be attributed to the presence of natural nests around the culture, since in this region it is not usual to rent beehives as pollinators for crop flowers. According to Winfree et al. (2009) and Garibaldi et al. (2011) 
this bee may be less affected by the effects of anthropogenic disturbance of the countryside landscape when compared to solitary bees.

Comparing melon hybrids, it was found that flowers of Sancho were more attractive to $A$. mellifera, indicating that simultaneous cultivation of both hybrids could result in competition for pollinator attraction. However, with regard to the behavior of $A$. mellifera throughout the day, it was that for both hybrids, a lower number of visits occurred during the early morning, which was also observed by Kiill et al. (2011, 2012), in the municipality of Petrolina, state of Pernambuco, Brazil in different cultivars of melon. However, the opposite was observed by Sousa (2008) and Sousa et al. (2012) in studies with this cucurbit in the region of Acaraú, state of Ceará, Brazil. This difference in visitation pattern observed for the same crop in different regions can be related to the climatic conditions of the location. In the present study, the observations were made in July, which is considered a month with mild temperatures (Teixeira 2010), and might explain concentration of visitors in warmer hours of the day.

In both melon hybrids, the peak of visitation was recorded from 10:00 am to 11:00 am with a concentration of visits in the morning. The same pattern was observed by Hoz (2007) in melon crops in Panama. Similarities were also observed between the two melon hybrids when comparing the floral type and resource foraged. The hermaphrodite flowers were visited more frequently than male flowers and this preference for this floral type may be associated with the quantity and quality of resources foraged, but further studies are needed to confirm this hypothesis. On the other hand, the production of male flowers in greater quantities is important to ensure the pollen flow in the crop, as well as a food source, and the fact that hermaphrodite flowers of Sancho are more attractive than the 'Yellow' hybrid suggests that the higher frequency of visits would lead to greater deposition of pollen grains which, in turn, would enable the formation of best quality fruits (Reyes-Carrillo et al. 2009).

In relation to foraged resource the pollen collection concentrated in the morning and the nectar collection observed during the whole day is in accordance with the pattern observed by $\mathrm{Hoz}$ (2007) and Siqueira et al. (2011) and indicates that this difference can be related with the constant production of nectar by flowers attracting bees throughout the day.

The analysis of the recorded data leads us to conclude that there was difference in the frequency of visits of $A$. mellifera when comparing melon hybrids cultivars, although, the foraging behavior was similar. This difference in frequency of visitation indicates that the flowers of Sancho are more attractive to A. mellifera and this can be related to the morphology and/or floral supply resources of these melon hybrids. Thus, the 'Yellow' hybrid could have limited its productivity by competing with Sancho, and this fact could be solved by scaling the plantation, avoiding overlapping of the flowering period of the melon hybrids.

\section{ACKNOWLEDGMENTS}

We thank the Conselho Nacional de Desenvolvimento Científico e Tecnológico (CNPq), Brasília - Brazil, for financially supporting the project "Evaluation of the efficiency of pollination services in the increment of melon (Cucumis melon L. Cucurbitaceae) production in the Brazilian semiarid" (proc. 556055/2009-8).

\section{RESUMO}

O presente trabalho foi realizado com o objetivo de verificar se há diferenças na frequência e no comportamento de forrageamento de Apis mellifera em dois híbridos de melão (10:00 - melão Amarelo e Sancho - melão Pele de Sapo) no município de Juazeiro, estado da Bahia, Brasil. A frequência e o comportamento dos visitantes e o recurso floral forrageado foram registrados, no período de 05:00 h às 18:00 h. Verificouse que houve diferença significativa na frequência de 
visitas na comparação entre os híbridos $(\mathrm{F}=103,74$; $\mathrm{p}<0,0001)$, o tipo floral $(\mathrm{F}=47,25 ; \mathrm{p}<0,0001)$ e o recurso forrageado $(\mathrm{F}=239,14 ; \mathrm{p}<0,0001)$. As flores do Sancho foram mais atrativas a Apis mellifera quando comparadas com o híbrido 10:00, o que pode estar correlacionado com a morfologia e oferta de recursos florais. Isto pode ser contornado, com a realização do plantio escalonado, evitando a sobreposição do período de floração dos dois tipos de meloeiro.

Palavras-chave: Cucumis melo L, híbridos de melão, néctar, polen.

\section{REFERENCES}

Abreu TB, NunEs GHDES, DANTAS MSM, Costa Filho JH, Costa GG AND ARAgÃo FAS. 2008. Fenologia floral, viabilidade do grão de pólen e receptividade do estigma do meloeiro. Proc Inter Soc Trop Hort 52: 43-46.

GARIBALDI LA ET AL. 2011. Stability of pollination services decreases with isolation from natural areas despite honey bee visits. Ecol Lett 14(10): 1062-1072.

Hoz JCT. 2007. Visita de abejas (Apis mellifera, Hymenoptera: Apoidea) a flores de melón Cucumis melo (Cucurvitaceae) en Panamá. Rev Biol Trop 55(2): 677-680.

IMPERATRIZ-FONSECA VL AND NUNES-SILVA P. 2010. As abelhas, os serviços ecossistêmicos e o Código Florestal Brasileiro. Biot Neotrop 10(4): 59-62.

KiILl LHP, Coelho MS, SiqueIRA KMM AND COSTA ND. 2011. Avaliação do padrão de visitação de Apis mellifera em três cultivares de meloeiro em Petrolina-PE, Brasil. Rev Bras Frut 33: 455-460.

KIILl LHP, COELHO MS, SIQUEIRA KMM, RIBEIRO MF, COSTA ND, FERNANDES NS AND SILVA TA. 2012. Relationship of floral morphology and biology of yellow melon hybrids with the attractiveness of pollinators. Magistra 24: 143-149.
KOUONON LC, JACQUemart AL, BI AIZ, Bertin P, BAUdoIN JP AND DJE1 Y. 2009. Reproductive biology of the andromonoecious Cucumis melo subsp. agrestis (Cucurbitaceae). Ann Bot 104: 1129-1139.

Reyes-CARrillo MCJL, CANO-RIos P AND CAMBERos UN. 2009. Período óptimo de polinización del melón con abejas melíferas (Apis mellifera L.). Agric Téc Méx 35(4): 371-378.

REyes-CARrillo MCJL, CANo-Ríos P, EISCHEN FA, RODRÍGUES-MARTÍNEZ R AND NAVA-CAMBEROS U. 2006. Spatial and temporal distribution of honeybee foragers in a cantaloupe field with different colony densities. Agric Téc Méx 32(1): 39-44.

SAS InSTITUTE. 2003. Sas user's guide: statistics. North Caroline; Cary, 846 p.

SiQUEIRA KMM, KIILl LHP, GAMA DRS, ARAUJO DCS AND COELHO MS. 2011. Comparação do padrão de floração e de visitação do meloeiro do tipo amarelo em Juazeiro-BA. Rev Bras Frut 33: 473-478.

SousA RM. 2008. Polinização, Manejo de Colmeias e Requerimentos do Meloeiro. In: SOBRINHO RB, GUIMARÃES JA, FREITAS JAD and TERAO D (Eds), Produção Integrada de Melão. Embrapa Agroindústria Tropical, Banco do Nordeste do Brasil, Fortaleza, CE, Brasil, p. 173-180.

SOUSA RM, AgUIAR OS AND FrEITAS BM. 2009. Requerimentos de polinização do meloeiro (Cucumis melo 1 .) no município de Acaraú - CE - Brasil. Rev Caat 22(1): 238-242.

Sousa RM, Aguiar OS, Freitas BM, Maracajá PB AND ANDRADE CBCM. 2012. Grazing behavior of africanized honey bees (Apis mellifera L.) in flowers of yellow melon (Cucumis melo L.) Rev Verde 7(1): 233-238.

TEIXEIRA AHC. 2010. Informações agrometeorológicas do Pólo Petrolina, PE/Juazeiro - 1963 a 2009. Petrolina: Embrapa Semiárido, 2010. 21 p. (Embrapa Semiárido. Documentos, 233).

Winfree R, Aguilar R, VÁzQuez DP, LEBUHN G AND AIZEN MA. 2009. A meta-analysis of bees responses to anthropogenic disturbance. Ecol 90: 2068-2076. 
